\title{
Intra-arterial Transplantation of Human Umbilical Cord Blood Mononuclear Cells in Sub-acute Ischemic Stroke Increases VEGF Expression in Rats
}

\author{
Ramli $\mathrm{Y}^{1 \#}$, Alwahdy AS ${ }^{1 \#}$, Kurniawan $\mathrm{M}^{1}$, Juliandi $\mathrm{B}^{2}$, Wuyung $\mathrm{PE}^{3}$
}

\begin{abstract}
Thrombolysis (rt-PA) is the only United States Food and Drug Administration (FDA) approved drug currently available. Unfortunately, its effect has been limited by the narrow therapeutic time window. Human cord blood mononuclear cells (cbMNC) is a promising treatment for ischemic stroke by forming collateral and neo-vascularization where it is one of the important factors that contribute to cell repair. Therefore, evaluation of neo-vascularization in sub-acute stroke may be beneficial for recovery. One group for healthy rat and three groups ( $\mathrm{n}=6$ per group) of male wistar rats have undergone permanent middle cerebral artery occlusion (MCAO). Transplantation $1 \times 10^{6}$ cells $/ \mathrm{kg}$ of human cbMNC intra-arterially (IA) and intra-venously (IV) were administered after 7 days. Behavioural tests were performed before MCAO, 1 week after MCAO and at 3,9 and 14 days after cbMNC transplantation. Beta III tubulin protein (TUJ1), glial fibrillary acidic protein (GFAP) and vascular endothelial growth factor (VEGF) antibody marker were evaluated. Spontaneous activity of transplanted rats by cbMNC have significantly improved compared to placebo group $(\mathrm{p}<0.05)$. Angiogenesis in IA group showed significant difference $(\mathrm{P}<0.001)$ when compared to IV and placebo respectively. The existence of neovascularization in the transplanted rats of cbMNC provide hope in accelerating repairment of the neuronal cells and functional outcome.
\end{abstract}

Key Words: Angiogenesis, Human umbilical cord blood, Mononuclear cells, Neurogenesis, Rats

\section{Introduction}

Transplantation of human cbMNC and their components (i.e., hematopoietic stem cells (HSCs), mesenchymal stem cell (MSCs), and endothelial progenitor cells (EPCs)) have also been shown to be effective in animal models of ischemic stroke by decreasing apoptosis, inflamation in periinfarct area and stimulate angiogenesis, whether it was given by intra-arterially, intravenously nor intra-parenchymally ${ }^{[1]}$. First and second phase of study have shown injection of stem cells for acute and sub-acute ischemia stroke were safe ${ }^{[2]}$.

It has no doubt that during acute phase is the best time to save the cell neurons in penumbra area. Moreover, it is reasonable when recanalization in acute phase occured will give more blood supply and minimalized the occuring of cell death.

However, to have succesfull reperfusion after the recanalization it depends on many factors. In human, comorbidities that will influence the outcome after recanalization have been identified and reported such as the formation of collateral, time of onset, high blood glucose, hypertention, NIHSS and dehydration ${ }^{[3]}$. Since the collateral formations are important for outcome after stroke, understanding the effect of human cbMNC on angiogenesis and its potency for accelerating repairment of neuronal cells that would contribute to funcional outcome will give alternative therapy in the future. In addition, after recanalization, reperfusion with less complications may be achieved by intra-arterial human cbMNC transplantation ${ }^{[4]}$.

As reported before, human cbMNC as hematopoietic cells contains not only angiogenic growth factors but also many factors that contributed to the neurogenesis through its paracrine effects ${ }^{\left[{ }^{[-7]}\right.}$. In addition, angiogenesis and neurogenesis is something that could not be seperated, where angiogenesis could stimulate neurogenesis and helping migration of progenitor cells to the periinfarct site ${ }^{[8]}$.

The effect of cbMNC in blood vessels was reported by Huang L et al $(2017)^{[1]}$ that intra-arterial administration of Human cbMNC in ischemic stages of hyper acute phase may increase cerebral blood flow $(\mathrm{CBF})$, cerebrovascular reactivity and vascular function. Unfortunately, the effect of transplantation cbMNC in sub-acute phase are remain uncertain especially in contributing to the neuronal cells repair and functional outcome despite during that time the cells within the penumbra area could not be saved anymore. The time from the onset of stroke to arterial recanalization significantly impacts outcomes ${ }^{[9]}$ and it will reduce its complications such as bleeding and edema.

By this study, we evaluated the administration of human cbMNC in rats with subacute phase of ischemic stroke. We hypothesize that intra-arterial administration of cbMNC in the subacute phase will still form neo-vascularization that will improves the functional recovery and contributes to the neurogenesis.

Author Names in full: Yetty Ramli" ${ }^{\#}$, Ahmad Sulaiman Alwahdy ${ }^{1 \#}$, Mohammad Kurniawan ${ }^{1}$, Berry Juliandi ${ }^{2}$, Puspita Eka Wuyung ${ }^{3}$

${ }^{1}$ Neurology Department, Medical Faculty University of Indonesia/ Ciptomangunkusumo National Hospital, Indonesia; ${ }^{2}$ Biology Department, Institut Pertanian Bogor, Indonesia;

${ }^{3}$ Pathology Anatomy Department,University of Indonesia/ Ciptomangunkusumo National Hospital, Indonesia

\# These authors contributed equally to this work 


\section{Materials and Methods}

\section{Permanent MCAO model}

One group for healthy rats and three groups ( $n=6$ per group) of 250 $300 \mathrm{~g}$ of male wistar rats underwent permanent middle cerebral artery occlusion (MCAO) by using flame -blunted monofilament that already have been reported in our publication (technique were not shown $)^{[10]}$, where group 2 treated with physiological fluid intraarterially, group 3 treated with cbMNC intra-arterially and group 4 treated with cbMNC intra-venously. Behavioural tests were performed before MCAO, 1 week after MCAO and at 3,9 and 14 days after cbMNC injection (data were not shown) ${ }^{[11]}$. Neurogenesis in hippocampus, neovascularization in periinfarct area were identified. One week after occlusion, the rats were injected by cbMNC with $1 \times 10^{6}$ cells $/ \mathrm{kg}$ that has been characterized by $\operatorname{cd} 34+(7 \%)$ intraarterially and intravenously. Two weeks after transplantation, all rats were euthanised and immunohistochemistry staining by beta III tubulin protein (TUJ1), glial fibrillary acidic protein (GFAP) and vascular endothelial growth factor (VEGF) antibody marker were evaluated (Figure 1).

\section{cbMNC isolation}

Cord blood sample obtained from cryopreservation that was not used by Cellsafe International coorporation. All cord blood units tested negative for human immunodeficiency virus, hepatitis $\mathrm{C}$ virus, hepatitis B virus, human T-cell lymphotrophic virus, and syphilis. Cord blood suspension was processed using gradient centrifugation method as follows: Use of aseptic technique procedures and Biosafety Cabinet operation (Esco BSC Class II). Cryopreserved cord blood samples were thawed and washed using water bath (memmert) then moved cord blood samples to $15 \mathrm{ml}$ tube and adding PBS solution (Gibco) with ratio sample and PBS was 1:2. Centrifuged at $1500 \mathrm{rpm}$ for 10 minutes (Thermo Scientific). Washing was done 2 times. Ficoll-Hypaque solution was put in $15 \mathrm{ml}$ tube. The washed cord blood was pipetted carefully into a tube contain Ficoll-Hypaque. The volume ratio of bone marrow suspension: Ficoll-Hypaque $=1: 1$. Centrifuge was performed at $2200 \mathrm{rpm}$ for $10 \mathrm{~min}$ at $20^{\circ} \mathrm{C}$, centrifugation termination did not use brakes (to prevent disorganization of fractions of separate components). Buffy coat layer (the layer contains nucleated cells) were taken using a pipette slowly and transferred to $15 \mathrm{ml}$ centrifuge tube. The buffy coat of erythrocytes was washed using lysis buffer as much as $3 \mathrm{ml}$. The buffy coat of lysis buffer was cleaned by using $\mathrm{NaCl}$ as much as $4 \mathrm{ml}$ and the number of cells counted with a counting chamber and trypan blue staining (Sigma).
Characterization od CD 34 from cbMNC.

Isolated cbMNC was characterized by using flow-cytometry method and using CD 34 kit enumeration. For analysis, 50 $\mu 1$ sample by adding $20 \mu \mathrm{l}$ solution of 7-AAD and $20 \mu \mathrm{l}$ combination reagent antibody were incubated for 65 minutes in dark room within BD falcon-round bottom tube $5 \mathrm{ml}$ (Beckton Dickinson 352063). After incubation, $6 \mathrm{ml}$ reagent from $\mathrm{BD}$ faschflow sheath fluid (Beckton Dickinson 342003) were put into the sample then incubated for 60 minutes. After incubation, sample was analyzed by using flowcytometry (FACS Calibur) where CD 34+ showed 7\%. After isolation of cbMNC, calculation of cell ammount and purity of its cell component using Hematology Analyzer (Syysmex KX21).

\section{Transplantation of cbMNC Procedures}

On the 7th day after ischemic condition, the experimental animals received a transplantation $1 \times 10^{6}$ cells $/ \mathrm{kg}$ of mononuclear cells in 400 $\mu \mathrm{l}$ of sodium chloride suspension. In the group treated with transplantation intravenously, cells were injected slowly through the tail vein of rats. In the group treated with transplantation intraarterially, cells were slowly injected through the common carotid artery on the contralateral side of the artery occluded within 20 seconds. Laser-Doppler flowmetry measurement would be helpful to analyze the prevent crebral blood flow (CBF) reduction during transplantation. However, less than $70 \%$ drop from baseline $\mathrm{CBF}$ would not correlate with infarct volume. In some cases this cut-off has been varied $(60 \%, 80 \%$ or as high as $85 \%)$, in both mouse and rat studies. Below $70 \%$ drop from baseline $\mathrm{CBF}$ has been a popular choice where tissue will become irreversible injured during MCAO. This data are debatable, since many factors that could influence why changes in $\mathrm{CBF}$ did not correlate to produce infarct lession such as the placement of the probe. Moreover, within less than 20 seconds and insertion through CCA, infarct were unlikely to be produced because blood flow to brain hemisphere would still be supplied by other collateral arteries. In addition, a reduction in CBF over the course of occlusion, significantly so after a $45 \mathrm{~min}$ occlusion, compared to shorter occlusion times, and the trend was also evident in all occlusion longer than $15 \mathrm{~min}^{[12]}$.

\section{Assessment of neurologic déficit}

Clinical experimental animals were assessed by a cylinder test and its spontaneous activity was assessed before the media cerebral artery occlusion, 7 days after occlusion and at 3,9 and 14 days after implantation. Cylinder test:In this test, rats were put in cylinder glass

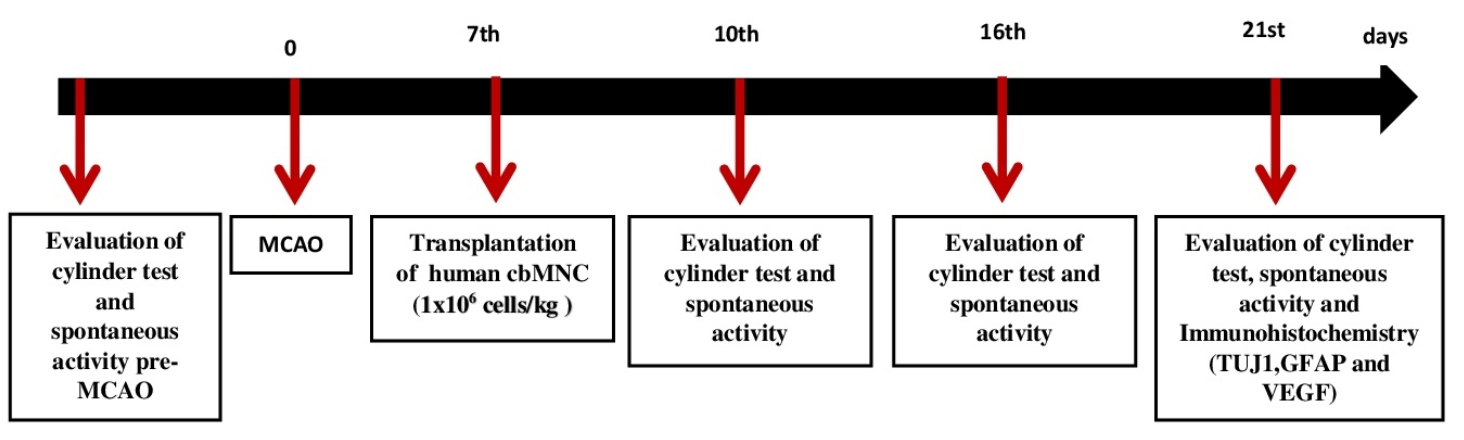

Group 1: Healthy rats

Group 2: MCAO + Injection normal saline intraarterially

Group 3 : MCAO + Human cbMNC transplantation intraarterially

Group 4 : MCAO + Human cbMNC transplantation intravenously

Figure 1. Study design 
tube $(10 \mathrm{~cm}$ in diameter and $15 \mathrm{~cm}$ in height). Rat will put the limb in a glass tube vertically. Analyzing the results of the test was by recording and observing which limb was more dominant in contact with the tube.

\section{Formula score of asymmetry extremity use $=$ Ipsilateral /(Ipsilateral+Contralateral+Both) - Contralateral/ $(\text { Ipsilateral+Contralateral }+ \text { Both })^{[13-15]}$.}

Initiation to move test was performed to evaluate the spontaneous activity. This technique has the advantage that it is quite easy to put a rat in a cage and counted the time the rat takes to move as far as its body length $(7 \mathrm{~cm})$ and recorded. ${ }^{[16,17]}$.

\section{Immunohistochemistry evaluation}

On day 21 after MCAO or 14 days post transplantation, the experimental animals were euthanized, perfused transcardially with PBS ( $\mathrm{pH}$ 7.4) followed by $10 \%$ buffered formalin. Brains of experimental animals were taken and cut serially between +1 to -1 bregma. The brain is collected and immersed in paraffin solution then proceed with immunohistochemistry examination on the same piece of each group. Image J software by the National Institutes of Health $(\mathrm{NIH})$ was used. The mice brain was cleaned from paraffin with xylol I for 10 minutes, xylol II for 10 minutes, xylol III for 10 minutes, absolute alcohol for 5 minutes, $95 \%$ alcohol for 5 minutes, $80 \%$ alcohol for 5 minutes, $70 \%$ alcohol for 5 minutes, then Aquadest for 5 minutes.

After these processes, endogenous blocking using peroxidase (3\% $\mathrm{H}_{2} \mathrm{O}_{2}$ in methanol) was carried out for 10 minutes, followed by 2 times washing with phosphate buffer saline (PBS) pH 7.4, each for 5 minutes. Then the preparation was inserted in retrieval solution antigen with Sodium Citrate Buffer pH 6.0 in pressure cooker for 10 minutes at $95^{\circ} \mathrm{C}$. After the process is complete, the preparation is chilled at room temperature for 45 minutes. Subsequent washing of the preparation was with PBS with $\mathrm{pH} 7.4$ twice, each for 5 minutes. Blocked nonspecific activity with Background snipper for 15 minutes. Primary antibody incubation: VEGF A (Anti-VEGF A ab46154, Rabbit polyclonal, abcam product) with dilution 1: 150, GFAP (Anti-GFAP ab7260, Rabbit polyclonal, abcam product) with dilution 1: 5000, Anti-beta III tubulin (Anti-beta III tubulin ab18207, Rabbit polyclonal, abcam product) with 1: 400 dilutions in PBS overnight, then 2 times washed with PBS pH 7.4 each for 5 minutes and was given biotinated link for 30 minutes. In the next step, the secondary antibody was incubated for 20 minutes and 2 times washed with PBS pH 7.4 every 5 minutes. After that, Trek-Avidin-HRP incubation was performed for 15 minutes. The next step was washing it with PBS pH 7.4 twice for each of 5 minutes, then with DAP for 5 minutes. Then it was washed with PBS $\mathrm{pH}$ 7.4. Counterstain done with Hematoxylin for 5 seconds. The preparations were washed with running water, then dehydrated with stratified alcohols (alcohols $70 \%, 80 \%, 96 \%$, absolute alcohols) for 3 minutes, xylol I, II and III respectively for $5 \mathrm{~min}$, and finally closed with hangings. Preparation was observed by light microscopy and photographed using 200x and 400x magnification (Nikon eclipse TE 2000-U, Japan). Positive cells were calculated by taking the average of five viewing fields viewed.

\section{Data processing}

Data were analyzed using Statistical Product and Service Solution (SPSS) program version 20. After Normalizing the data, one-way ANOVA analysis were performed in histopathology evaluation. Kruskal Wallis analysis were done when the data was not distributed normally. Behavioural evaluations were analyzed by using two-way ANOVA between the period of time in each group and LSD post- hoc analysis were performed when there was significant difference between group. $(\mathrm{p}<0.05)$.

Research ethics

This research was approved by the research ethics of medicine / health Medical Faculty of Universitas Indonesia no:789/UN2.F1/ETIK/2016.

\section{Results}

cbMNC intra-arterial and intra-venous in promoting motor coordination

In our previous study, prior to surgery on rats all groups showed a balanced use of extremity and showed no significant difference ( $\mathrm{p}>$ $0.05)$. Following the MCAO, there were differences in rats of using their extremity, which in the treatment groups $(2,3$ and 4$)$ used the extremity that was not paralyzed more often than the healthy group $(\mathrm{P}<0.05)$. Three days post-transplantation significant difference was not found statistically compared between groups with $(\mathrm{p}>0.05)$. On day 9 of post transplantation there were significant differences between groups with $p<0.05$. In group 4 at 3 days post transplantation obtained better improvement than the other treatment groups. On the other hand, the third group showed no improvement at day 3 or 9 post transplantation, but showed positive trends at 14 days post transplantation (data were not shown) ${ }^{[11]}$.

\section{cbMNC intra-arterial and intra-vena promote improvement in spontaneous activity}

In the analysis of spontaneous activity, statistically significant differences occurred at day 7 post-occlusion, 3, 10 and 14 days post transplantation with $\mathrm{p}<0.05$. A significant difference was found in all treatment groups compared to normal rats $(\mathrm{P}<0.05)$. It was clear that occlusion slowed down spontaneous activity in all treatment groups. Significant differences were found in the placebo group compared to transplanted cbMNC group intra-arterially and intra-venously with $\mathrm{P}<0.05$ (data were not shown) ${ }^{[11]}$.

Effect of transplantation of human cbMNC on neurogenesis, gliosis process and angiogenesis.

\section{Neurogenesis in the hippocampus area}

In this study, antibodies to beta-III tubulin proteins (TUJ1) were used as a marker of immature neurons in dentate gyrus, where in rats with MCAO, expression of beta-III tubulin protein can be expressed after 1 week during mitosis phase and it also can be expressed in the post mitosis phase ${ }^{[18]}$. Looking at the result in the dentate gyrus, beta-III tubulin proteins were more expressed by cells in group 3 and 4 compared to group 1 and 2 (Figure 2). When we compared quantitavely, there were significant differences between transplanted group compared to normal group $(\mathrm{p}<0.05)$ but not with group 2 (Table 1).

In the hippocampus area, cells that expressed GFAP were also evaluated. At the subgranular zone (SGZ) in hippocampus, cells that expressed GFAP were indicated as progenitor stem cells, but at hilus the expression of GFAP were marker for astrocytes that contributed in developing of adult neurogenesis. In the SGZ area, neuronal cells that expressed GFAP were much more in group 3 and 4 compared to other groups where significant difference was found only in group 3 compared to other groups $(\mathrm{P}<0.05)$. However, group 4 showed an increment of the cells that expressed GFAP, unfortunately it was not statistically different. On the other hand, when comparison of cells that expressed GFAP in hilus area were evaluated, there were no statistically different among the groups. (Table 2) 

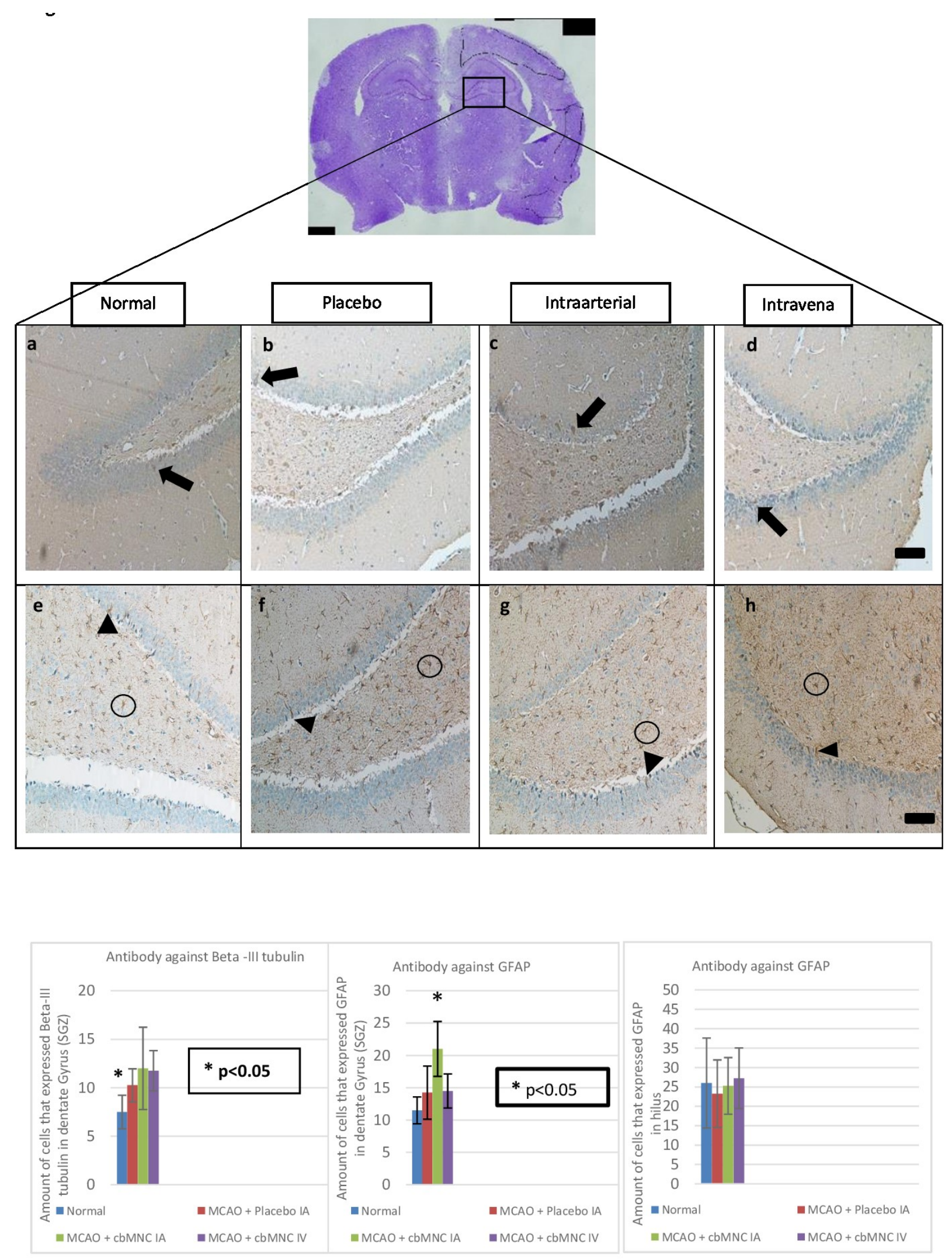

Figure 2. There were more cell neurons that expressed beta-III tubulin protein in dentate gyrus (black arrow) in group 3 (c) compared to group 4 (d), group 2 (b) and group 1 (a). Cell neurons that expressed GFAP in dentate gyrus (black arrow head) were found more in group 3 (g) compared to other groups (e,f dan h). In hilus area (black circle) the amount of cell neurons that expressed GFAP did not show significant differences. The differences of cell amounts that expressed beta-III tubulin protein and GFAP in subgranular zone are showing in $i$ and $j$. The cells that expressed GFAP in hilus are showing in (k). Magnified by $200 x$ magnification. Scale bar $=50 \mu m$. 
Table 1. Transplantation effects of human cbMNC by increasing the expression of beta-III tubulin proteins in dentate gyrus area.

\begin{tabular}{lccc}
\hline \multicolumn{1}{c}{ Group } & No & Dossage of cbMNC & Dentate gyrus (mean \pm SD) \\
\hline 1. Normal & 6 & - & $7,50 \pm 1,73$ \\
2. Placebo Intraarterially & 6 & $1 \times 10^{6}$ cells/kg & $10,25 \pm 1,70$ \\
3 Intraarterially & 6 & $1 \times 10^{6}$ cells $/ \mathrm{kg}$ & $12,00 \pm 4,24$ \\
4 Intravenously & 6 & $11,50 \pm 2,08$ \\
\hline
\end{tabular}

*Annova One Way with Post Hoc LSD where there was only group 1 has significant difference result compared to group 2, 3 and 4.

Table 2. Transplantation effects of human cbMNC by increasing the expression of GFAP in dentate gyrus and hilus area.

\begin{tabular}{lccccc}
\hline \multicolumn{1}{c}{ Group } & No & $\begin{array}{c}\text { Dossage of } \\
\text { cbMNC }\end{array}$ & $\begin{array}{c}\text { Dentate gyrus } \\
\text { (mean } \pm \text { SD) }\end{array}$ & P & Hilus (mean \pm SD) \\
\hline 1. Normal & 6 & - & $11,50 \pm 2,08$ & $26,00 \pm 11,66$ \\
$\begin{array}{l}\text { 2. Placebo } \\
\text { Intraarterially }\end{array}$ & 6 & - & $14,25 \pm 4,11$ & $23,25 \pm 8,77$ \\
3 Intraarterially & 6 & $1 \times 10^{6}$ cells $/ \mathrm{kg}$ & $21,00 \pm 4,24$ & $<0.05^{*}$ & $25,25 \pm 7,32$ \\
4 Intravenously & 6 & $1 \times 10^{6}$ cells/kg & $14,50 \pm 2,64$ & $27,25 \pm 7,80$ \\
\hline
\end{tabular}

* Annova One Way with Post Hoc LSD where there was only group 3 has significant difference result compared to group 1, 2 and 4.

In the peri-infarcts area, we also calculated the number of activated astrocytes as a result of ischemic stroke. The gliosis process in acute phase may have protective benefits as a barrier to inflammatory or infectious factors, but then the gliosis tissue can become permanent tissue, making it difficult for post-stroke healing process and inhibiting neurogenesis by inhibiting the regeneration of axon ${ }^{[19]}$. We hypothesize that transplantation in this experimental study (subacute phase) will not be having an effect in reducing infarct area since gliosis may already be permanent, and the cells within the penumbra area will not be saved. Regarding the aim of this study, the evaluation was focused on how cbMNC can induce angiogenesis by forming collateral vascularization and whether thus neovascularization can stimulate neurogenesis and its effect in functional outcome. Therefore, antibody against GFAP was used to see the amount of reactive astrocytes in periinfarct area (Figure 3).

The amount of cells that expressed GFAP did not differ significantly between group 2, group 3 and group 4 , but was significantly different when compared to normal rats (group 1) with $\mathrm{P}<0.001$ (Table 3).

Table 3. Transplantation effects of human cbMNC in gliosis process within periinfarct area by evaluating the expression of GFAP.

\begin{tabular}{|c|c|c|c|c|}
\hline Group & No & Dossage of cbMNC & Peri infarct $($ mean \pm SD) & $\mathbf{P}$ \\
\hline 1. Normal & 6 & - & $10,90 \pm 3,52$ & $<0.001^{*}$ \\
\hline 2. Placebo Intra-arterially & 6 & - & $15,00 \pm 4,68$ & \\
\hline 3 Intra-arterially & 6 & $1 \times 10^{6}$ cells $/ \mathrm{kg}$ & $14,67 \pm 4,53$ & \\
\hline
\end{tabular}

* Annova One Way with Post Hoc LSD where there was only group 1 has significant difference result compared to group 2, 3 and 4. 


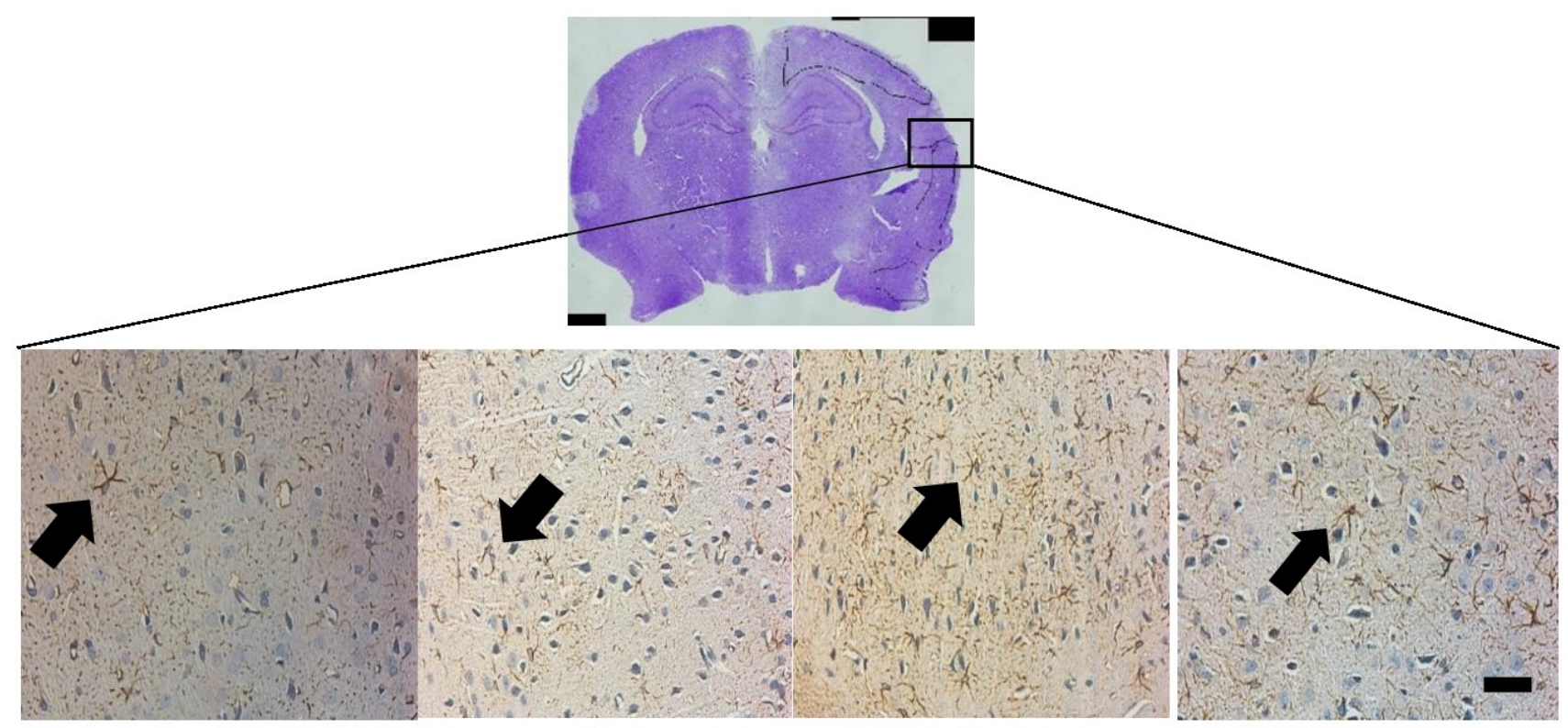

a)

b)

c)

d)

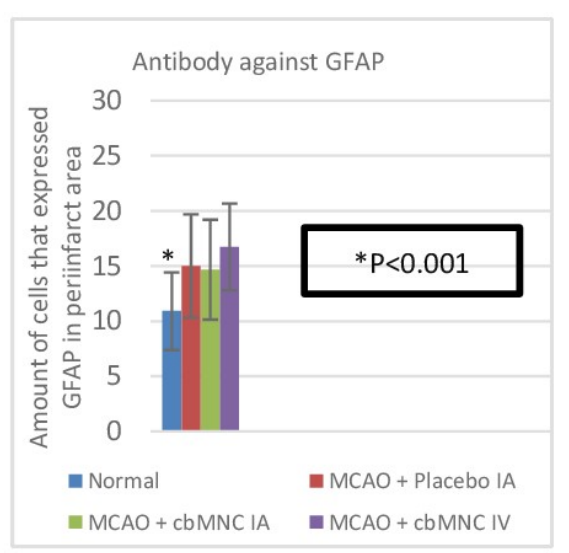

Figure 3. Active astrocyte in the peri infarct area with positive GFAP marker (arrow) in group 1 (a), group 2 (b), group 3 (c) and group 4 (d)). The comparison of cell amounts that expressed GFAP between groups in periinfarct area are showing in (e) with $400 x$ magnification. Scale bar $=50 \mu \mathrm{m}$.

\section{Angiogenesis in the peri infarct area}

In angiogenesis evaluation, antibody against VEGF was used. The cells that expressed VEGF were counted and qualitatively were noted. Surprisingly, the results showed significant difference between group 3 compared to other groups, where group 3 showed cells that expressed VEGF much more higher with $\mathrm{P}<0.001$ and $\mathrm{P}<0.05$ in group 4 compared to group 1 and 2 (Table 4 ). By this result, it seems that increment were related to the changes of structure of blood vessels where also suggesting a form of angiogenesis in the form of collaterals, sprouting, intussusception and widening of the capillary blood vessels $^{[20]}$ (Figure 4).

Table 4. Transplantation effects of human cbMNC in angiogenesis within periinfarct area by evaluating the expression of the cells to VEGF.

\begin{tabular}{lccc}
\hline \multicolumn{1}{c}{ Group } & No & Dossage of cbMNC & Peri infarct (mean \pm SD) \\
& & & \\
\hline 1. Normal & 6 & - & $55.67 \pm 16.64$ \\
2. Placebo Intra-arterially & 6 & $1 \times 10^{6}$ cells $/ \mathrm{kg}$ & $73.83 \pm 13.54$ \\
3 Intra-arterially & 6 & $1 \times 10^{6}$ cells $/ \mathrm{kg}$ & $90.17 \pm 13.10$ \\
4 Intra-venously & 6 & $80.00 \pm 18.48$ & $<0.001^{*}$ \\
\hline
\end{tabular}

* Annova One Way with Post Hoc LSD group 3 has significant difference result compared to other groups (P<0.001) and $\mathrm{P}<0.05$ was found when group 4 compared to group 1 and 2. 


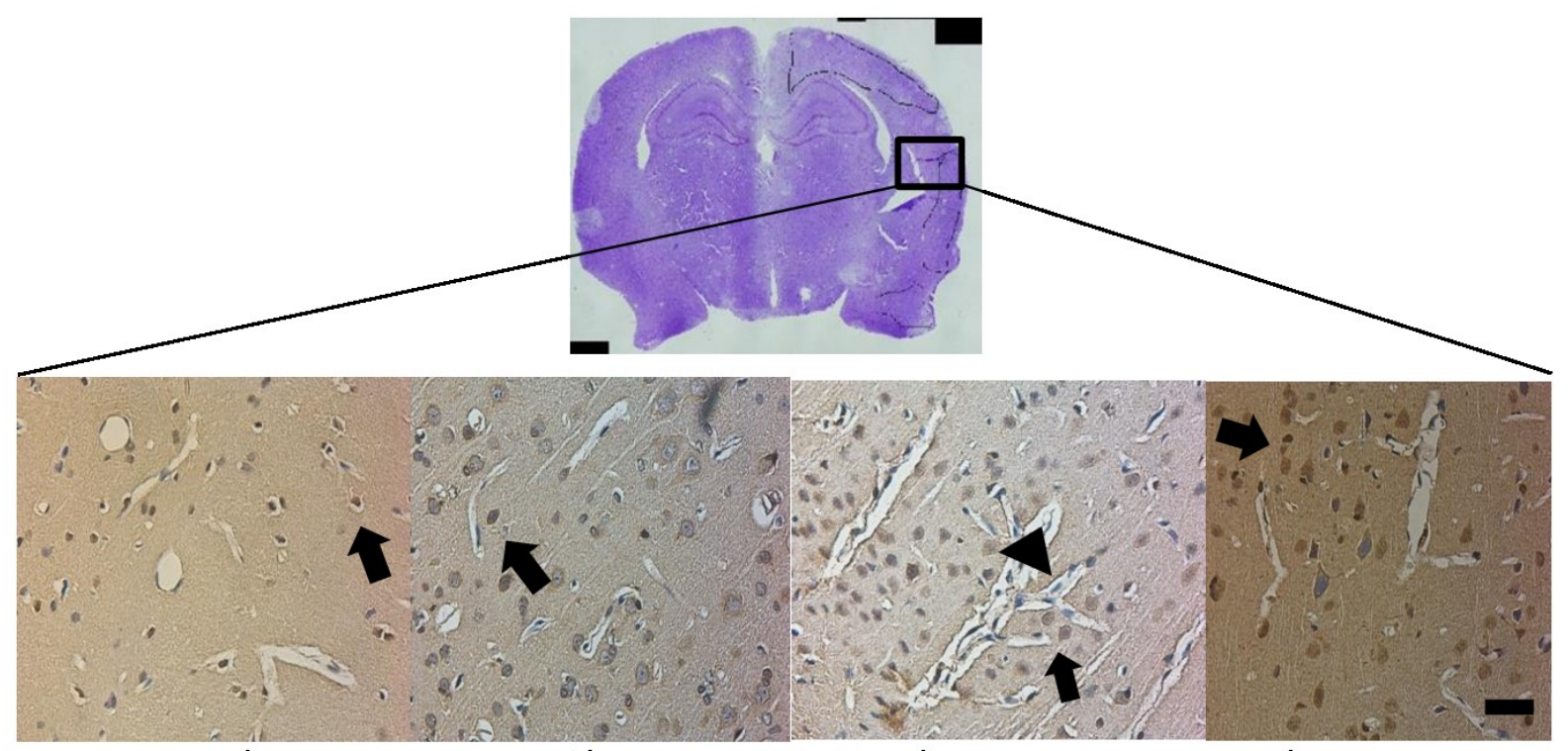

a)

b)

c)

d)

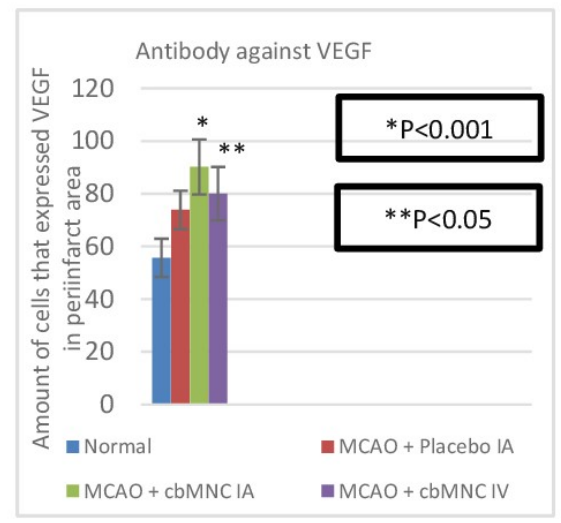

Figure 4. Cells that expressed VEGF (black arrow) and its effect to the changes of structure of blood vessels where also suggesting a form of angiogenesis in the form of collaterals, sprouting, intussusception and widening of the capillary blood vessels. Group 1 (a), group 2 (b), group 3 (c) and group 4 (d). The angiogenesis process appears more clearly in group 3 , with sprouting, dilation of blood vessels and intussusception (black triangle). The comparison of cell amounts that expressed VEGF between groups in periinfarct area are showing in (e) with 400x magnification. Scale bar $=50 \mu \mathrm{m}$.

\section{Discussion}

Human cbMNCs are potential source of cells in cell therapy for stroke. The advantages of human cbMNCs are due to their pluripotency, immaturity and availability. The problem in cell therapy are various such as finding the best source of the stem cells to be administered, the route of administration, the dosage and the best time to be administered. Many studies have attempted the effectiveness of stem cell therapy by differentiating the routes of administration (intra-arterially, intra-venously and intraparenchymally) with intra-arterial administration outcomes are having better outcomes than intra-venously, and safer than intraparenchymally ${ }^{[21]}$.

Human cbMNC also contains many factors that can contribute to the neurogenesis and angiogenesis process. Anti-inflammatory and growth factors such as VEGF and BDNF are one of the factors that have been found in cbMNC, where BDNF if administered intravenously may reduce the infarction area and mediate the proliferation of existing vascular endothelial cells, neuron cell migration and modulate synapse function ${ }^{[22,23]}$.
In addition, VEGF is also known to promote neurogenesis and inhibit apoptosis ${ }^{[24,25]}$ and can induce antiapoptotic pathways through phosphatidylinositol 0-kinase which ended with the inhibition of endothelial apoptosis ${ }^{[26]}$. In experiments with experimental animal performed by Ohtaki et al (2006) $)^{[27]}$, it was reported that on the mice after the occlusion and ischemia occurred, a positive reaction for VEGF increased along time.

The cells that express VEGF in ischemic stroke are found in the periinfarct region but not in the infarct region. VEGF is also expressed not only by endothelial cells but also expressed by other neuronal cells such as astrocytes. Furthermore, it has been reported that in the peri infarct area of 4 weeks after chronic stroke, VEGF was still can be found and this finding indicated angiogenesis and neovascularization in chronic stroke ${ }^{[27]}$. In other studies, pericyte of the brain's capillary can also promote VEGF secretion by stimulating the expression of $\mathrm{N}$-cadherin ${ }^{[28]}$.

In this study, we found that the number of cells that expressed VEGF were higher in transplanted groups compared to group 1 and 2 . 
Among the groups, intra-arterial group showed with significantly different results compared with other groups $(\mathrm{P}<0.001)$. In addition, this group also showed the existence of angiogenesis process which can be in form of sprouting, intussusception and widening of capillary blood vessels ${ }^{[20]}$ and it seems that the number of VEGF positive cells were related to the collateral blood vessels formation.

Eventhough VEGF was the marker that often be used for detecting angiogenesis, there are several markers that could help to detect angiogenesis such as CD31, where it also can be found on the surface of platelet cells, monocytes, macrophages and neutrophils. Those cells are also contributed in adhesion cascade between endothelial cells and it should be remembered that normal brain cells could expressed CD31 cells as a consequences of inflamation after infarct ${ }^{[29]}$. In addition, von Willebrand factor (vWF) may also be used as specific endothelial cell marker, but for endothelial progenitor cells (EPC) to be able to repair damaged tissue after ischemic and migration of EPC to be migrated to infarct area and differentiated to be mature endothelial cells need VEGF as its mediator ${ }^{[34]}$.

Unfortunately, there are still remain issues to be investigated regarding relation between neovascularization and its membrane permeabillity. It was reported that VEGF given alone in the acute phase (1-24 hours) after ischemic stroke may increase the permeability of BBB and caused bleeding. On the other hand, this result was not found if it is given at 48 hours post-stroke ${ }^{[13,30]}$, therefore, transplantation was done in sub-acute period.

In our study we characterized the viabillity of cbMNC only with CD34+, where it has been reported in previous studies that human CD $34+$ cells were shown to secrete numerous angiogenic factors, including VEGF, HGF and IGF-1 and act as a potent regulator of adult neurogenesis ${ }^{[31]}$. Therefore, we only delivered $7 \%$ of CD34+ where it was much more lesser than previous study that has been delivered by more than $80 \%$ of CD34+[24,25] since higher ammount of VEGF postive would give more neovascularization but at the same time the risk of bleeding and edema would also increase. Newly formed blood vessels will be matured and will begin their function on days 10 to 21 after VEGF administration and there was no increase in permeability of $\mathrm{BBB}^{[28]}$. Therefore, to evaluate the new forming of blood vessels in 14 days after transplantation was reasonable. Eventhough we did not evaluate the integrity of BBB, it showed no bleeding after transplantation of cbMNC in sub-acute phase. This result may suggest that in sub-acute phase transplantation of human cbMNC was safe, but it needs to be investigated further to find out its effect on membrane permeabillity of BBB.

Furthermore, pluripotency owned by human cbMNC also have endothelial progenitor cells (EPC) in which endothelial progenitor cells transplantation in ischemic tissue of experimental animals proved the existence of a better neovascularization in mice with ischemic extremity ${ }^{[32]}$. Several studies have been conducted to show that patient with low EPC had higher risk for experience atherosclerosis. In the EPC study of blood mononuclear cells ex vivo, focal neovascularization was found on the myocardium after acute myocardial infarct ${ }^{[33]}$.

To be able to repair tissue damage which caused by ischemic, the EPC need to be migrated to the ischemic area and differentiate into mature endothelial cells was needed. This process is mediated by growth factors such as G-CSF, VEGF, inflammatory factors such as IL-6, IL-10 and endothelial nitric oxide synthase (eNOS) ${ }^{[34]}$. Mobilization and EPC migration are also affected by some signal transduction in cells, including $\mathrm{CXCR} 4, \mathrm{SDF}-1$ and $\mathrm{CXC}$, but
CXCR4 is the majority of receptors expressed by EPC ${ }^{[35]}$. Based on the result, there was a possibility that other factors can contribute to the formation of blood vessels. Unfortunately we did not evaluate other factors such as BDNF, HGF, IGF-1 and EPC in this study and it needs to be investigated in the future.

In the sub-acute phase, the gliosis has occured and we hypothesized that transplantation would not give any beneficial effects in reducing the gliosis area and as a consequences, the cell neurons within penumbra area will not be saved. Based on that, we found that activated astrocytes were not having significant difference between transplanted and non-transplanted group, but significant difference only showed when compared to normal rats where the activated astrocytes had less amount $(\mathrm{P}<0.001)$. However, it has been reported where the effective results obtained if given before 48 hours post $\mathrm{MCAO}^{[36]}$ and it can reduced the infarct area ${ }^{[37,38]}$.

All the cells derived from cbMNC have their contribution to the neurogenesis and angiogenesis. Neurogenesis could be stimulated by inducing endogenous stem cells in subgranular zone, subventricle zone and subcortical area ${ }^{[5-7]}$. In addition, angiogenesis and neurogenesis is something that could not be seperated, where angiogenesis could stimulate neurogenesis. Therefore, we evaluated the number of cells that expressed GFAP and beta-III tubulin proteins in the SGZ as marker for immature neurons in adult neurogenesis.

The migration of cbMNC to peri-infarct area and how its mechanism in improving functional outcome is still unclear ${ }^{[26,39]}$ and paracrine effect has been purposed by many studies as its mechanism ${ }^{[38]}$. In adult neurogenesis, radial glia-like precursor cell has larger amount in SGZ and has astrocytic properties that expressed GFAP ${ }^{[17]}$. Progenitor neuronal cells in SGZ will make the connection between dentate gyrus, CA3 and CA1 and form circuits as known to be trisynaptic circuit ${ }^{[40]}$ and they will contribute to the functional outcome.

Under pathological conditions and extrenal stimulations will give different result in process of neurogenesis ${ }^{[41]}$, where the speed of maturation and proliferative activity of new neurons may be induced by external stimulations. Morphological changes after cbMNC transplatation were significant difference in hippocampus area, and thus findings suggest that there were different speed maturations and their proliferative activity of neurons in neurogenesis ${ }^{[11]}$. To understand further regarding this circumstances, we used immunohistochemistry staining by using GFAP and beta-III tubulin. After transplantation, we found that the number of cell neurons that expressed GFAP and beta-III tubulin were higher within dentate gyrus in cbMNC groups especially in intraarterial group $(\mathrm{P}<0.05)$. This is consistent with the results obtained either functionally from our previous report ${ }^{[11]}$ or quantitatively in this research that spontaneous activity where the memory process, cognitive function and learning process are involved ${ }^{[7]}$ where thus functions are controlled by hippocampus showed better result in transplanted group compared to group 2 .

It has been reported that the functions of astrocytes within hilus area are contributed in adult neurogenesis. Proliferative cell neurons are found in hilus and they express GFAP where thus cells are precursor cell neurons that will be migrated to SGZ and eventually develope into mature granular cell neurons ${ }^{[42]}$. Based on the results, there were no differences among the groups, and it might suggest that there is other mechanism which could stimulate neurogenesis in dentate gyrus except from proliferative cell neurons in hilus area. 
Surprisingly, in our previous research that has been published on the sensory motor function by using cylinder test did not show what we expected to have occurred where in group 2, it showed improvement even without administration of cbMNC ${ }^{[11]}$. In this situation, we hypothesize that there was some reaction where inflamatory factors were involved, since we used xenogenic experimental study. Moreover, it was reported in the administration of cbMNC there was non-significant decrease of IL6, IL $\beta$ and TNF alpha cytokines, thereby cbMNC abillity in improving functional outcome more due to its effect of growth factors that can reduce oxidative stress rather than its effect on reducing of proinflamatory factors ${ }^{[23]}$.

Unfortunately, we did not evaluate further on what inflamatory factors appeared after transplantation of cbMNC, since inflamation factors were not the aim of our study and this hypothesis need to be investigated further.

\section{Conclusion}

Eventhough transplantation of human cbMNC were given in the subacute phase ( 7 days post-occlusion), it still showed beneficial effects especially when delivered intra-arterially. The presence of more neovascularization in the peri-infarct area provide hope that human cbMNC would stimulate the formation of collateral blood vessels by increasing the expression of VEGF as an angiogenesis factor, furthermore, it also improves the functional outcome. In addition, these results also showed its effect on neurogenesis and it seems that cbMNC might be accelerating the proliferative activity of new neurons. In spite of their benefits, further research is needed to find out its effect on inflamatory factors and membrane permeabillity of BBB. Not using a double marker to labelling either the cbMNC directly giving rise to neurons and vasculature or whether the cells are stimulating proliferation and differentiation of endogenous cell types is a limitation of this study. To reduce the bias, we used healthy rats and placebo control as a comparison in calculating the amount of cells that express the marker after transplantation of cbMNC. From the result, we suggest that cbMNC-induced neurogenesis and angiogenesis through its paracrine effect.

\section{References}

1. Huang L, Liu Y, Lu J, Cerqueira B, Misra V, Duong TQ. Intraarterial transplantation of human umbilical cord blood mononuclear cells in hyperacute stroke improves vascular function. Stem Cell Res Ther. 2017;8(1):74..

2. Fruchtman SM, Hurlet A, Dracker R, Isola L, Goldman B, Schneider BL, Emre S. The successful treatment of severe aplastic anemia with autologous cord blood transplantation. Biol Blood Marrow Transplant. 2004;10(11):741-2..

3. Li S, Yin M, Zhou Z, Chen H. Dehydration is a strong predictor of long-term prognosis of thrombolysed patients with acute ischemic stroke. Brain Behav. 2017;7(11):e00849.

4. Fargen KM, Jauch E, Khatri P, Baxter B, Schirmer CM., Turk AS, Mocco J. Needed dialog:regionalization of stroke systems of care along the trauma model. Stroke. 2015;46(6):1719-26.

5. Altman J. Autoradiographic investigation of cell proliferation in the brains of rats and cats. Anat Rec. 1963; 145: 573-91.

6. Eriksson PS, Perfilieva E, Bjork-Eriksson T, Alborn AM, Nordborg C, Peterson DA, Gage FH. Neurogenesis in the adult human hippocampus. Nat Med. 1998; 4(11): 1313-7.

7. Kokaia Z, Lindvall O. Neurogenesis after ischaemic brain insults. Curr Opin Neurobiol. 2013; 13(1): 127-32.

8. Kojima T, Hirota Y, Ema M, Takahashi S, Miyoshi I, Okano H, Sawamoto K. Subventricular zone-derived neural progenitor cells migrate along a blood vessel scaffold toward the post-stroke striatum. Stem Cells. 2010;28(3):545-54.
9. Sheth SA, Jahan R, Gralla J, Pereira VM, Nogueira RG, Levy EI, Zaidat OO, Saver JL, SWIFT-STAR Trialists. Time to endovascular reperfusion and degree of disability in acute stroke. Ann Neurol. 2015;78(4):584-93.

10. Ramli Y, Alwahdy AS, Kurniawan M, Juliandi B, Wuyung PE, Susanto YDB. Permanent Flame-Blunted Monofilament of Middle Cerebral Artery Occlusion Technique for Ischemia Stroke Induction in Animal Models. Med J Indones. 2017;26 (3):183-9.

11. Ramli Y, Alwahdy AS, Kurniawan M, Juliandi B, Wuyung PE, Susanto YDB. Intravenous Versus Intraarterial Transplantation of Human Umbilical Cord Blood Mononuclear Cells for Brain Ischemia in Rats. Hayati J biosci. 2017; 24 (4): 187-94.

12. Garry PM, Amanda LW, Richard PT, Amandeus G, Lars MI, Bryce V. A Comparative Study of Variables Influencing Ischemic Injury in the Longa and Koizumi Methods of Intraluminal Filament Middle Cerebral Artery Occlusion in Mice.journal.pone. 2016;11 (2): 1-34

13. Balkaya M, Krober JM, Rex A, Endres M. Assesing post-stroke behavior in mouse models of focal ischemia. J Cereb Blood Flow Metab. 2013; 33(3): 330-38.

14. Zarruk JG, Garcia-Yebenes I, Romera VG, Ballesteros I, Moraga A, Cuartero MI, Hurtado O, Sobrado M, Pradillo JM, FernandezLopez D, Serena J, Castillo-Melendez M, Moro MA, Lizasoain I. Neurological test for functional outcome assesement in rodent models of ischemia stroke. Revista de neurologia. 2011; 53(10): $607-18$.

15. Hunter AJ, Hatcher J, Virley D, Nelson P, Irving E, Hadingham SJ, Parsons AA. Functional assessments in mice and rats after focal stroke. Neuropharmacology. 2000;39(5):806-16.

16. Lubjuhn J, Gastens A, Von Wilpert G, Bargiotas P, Herrmann O, Murikinati S, Rabie T, Marti HH, Amende I, Hampton TG, Schwaninger M. Functional testing in a mouse stroke model induced by occlusion of the distal middle cerebral artery. J Neurosci Methods. 2009;184(1):95-103.

17. Rosell A, Agin V, Rahman M, Morancho A, Ali C, Koistinaho J, Wang X, Vivien D, Schwaninger M, Montaner J. Distal Occlusion of the Middle Cerebral Artery in Mice:Are We Ready to Assess Long-Term Functional Outcome?.Transl Stroke Res. 2013; 4 (3): 297-307.

18. O. von Bohlen and Halbach. Immunohistological markers for staging neurogenesis in adult hippocampus. Cell Tissue Res. 2007 ;329(3):409-20.

19. Li L, Lundkvist A, Andersson D, Wilhelmsson U, Nagai N, Pardo AC, Nodin C, Stahlberg A, Aprico K, Larsson K, Yabe T, Moons L, Fotheringham A, Davies I, Carmeliet P, Schwartz JP, Pekna M, Kubista M, Blomstrand F, Maragakis N, Nilsson M, Pekny M. Protective role of reactive astrocyte in brain ischaemia. J Cereb Blood Flow Metab. 2008;28(3):468-81.

20. Honnegowda TM, Kumar P, Udupa EGP, Kumar S, Kumar U, Rao P. Role of Angiogenesis and angiogenic factors in acute and chronic wound healing. Plast Aesthet Res. 2015; 2: 243-9.

21. Guzman R, Choi R, Gera A, De Los Angeles A, Andres RH, Steinberg GK. Intravascular cell replacement therapy for stroke. Neurosurg Focus. 2008;24(3-4):E15.

22. Savitz SI, Rosenbaum DM. Stroke Recovery with Cellular Therapies. New Jersey: Humana Press, 2008: 29-47.

23. Karlupia N, Manley NC, Prasad K, Schafer R, Steinberg GK. Intraarterial transplantation of human umbilical cord blood mononuclear cells is more efficacious and safer compared with umbilical cord mesenchymal stromal cells in a rodent stroke model. Stem cell Res Ther. 2014; 5 (2): 45.

24. Deepti N, Shuzhen G, Ken A, Eng HL.Mechanisms and Targets for angiogenic therapy after stroke. Cell Adh Migr. 2009; 3(2): 216-23.

25. Ergul A, Alhusban A, Fagan SC. Harmonized Target for Recovery After Stroke. Stroke. 2012; 43(8): 2270-74.

26. Chen J, Zhu RL, Nakamaya M, Kawaguchi K, Jin K, Stetler RA, Simon RP, Graham SH. Expression of the apoptosis-effector gene, Bax, is up-regulated in vulnerable hippocompal CA1 neurons following global Ischemia. Journal of Neurochemistry. 1996; 67(1): 64-71. 
27. Ohtaki H, Fujimoto T, Sato T, Kishimoto K, Fujimoto M, Moriya M, Shioda S. Progressive expression of vascular endothelial growth factor (VEGF) and angiogenesis after chronic ischemic hypoperfusion in rat. Acta Neurochir. 2006; 96: 283-287.

28. Zechariah A, ElAli A, Doeppner TR, Jin F, Hasan MR, Helfrich I, Mies G, Hermann DM. Vascular Endothelial Growth Factor Promotes Pericyte Coverage of Brain Capillaries, Improves Cerebral Blood Flow During Subsequent Focal Cerebral Ischemia, and Preserves the Metabolic Penumbra. Stroke. 2013;44(6):1690-7.

29. Pusztaszeri MP, Seelentag W, Bosman FT. Immunohistochemical expression of endothelial markers CD31, CD34, von Willebrand factor, and Fli-1 in normal human tissues. J Histochem Cytochem. 2006;54(4):385-95.

30. Zhang ZG, Zhang L, Jiang Q, Zhang R, Davies K, Powers C, Bruggen Nv, Chopp M. VEGF enhances angiogenesis and promotes blood-brain barrier leakage in the ischemic brain $\mathrm{J}$ Clin Invest. 2000;106(7):829-38.

31. Taguchi A, Soma T, Tanaka H, Kanda T, Nishimura H, Yoshikawa $\mathrm{H}$, Tsukamoto $\mathrm{Y}$, Iso $\mathrm{H}$, Fujimori $\mathrm{Y}$, Stem DM, Naritomi H, Matsuyama T. Administration of CD34+ cells after stroke enhances neurogenesis via angiogenesis in a mouse model. J Clin Invest. 2004;114(3):330-8.

32. Madeddu P, Emanueli C, Pelosi E, Salis MB, Cerio AM, Bonanno G, Patti M, Stassi G, Condorelli G, Peschle C. Transplantation of low dose $\mathrm{CD} 34+\mathrm{KDR}+$ cells promotes vascular and muscular regeneration in ischemic limbs. FASEB J. 2004;18(14):1737-9.

33. Li ZQ, Zhang M, Jing YZ, Zhang W, Liu Y, Cui LJ, Yuan L, Liu $\mathrm{XZ}, \mathrm{Yu} \mathrm{X}, \mathrm{Hu}$ TS. The clinical study of autologous peripheral blood stem cell transplantation by intracoronary infusion in patients with acute myocardial infarction (AMI). Int J Cardiol. 2007 ;115(1):52-6.

34. Bogoslovsky T, Spatz M, Chaudhry A, Maric D, Luby M, Frank J, Warach S, NINDS Natural History of Stroke Investigators. Stromal -derived factor-1[alpha]correlates with circulating endothelial progenitor cells and with acute lesion volume in stroke patients. Stroke. 2011; 42(3): 618-25.

35. Chen J, Chen S, Zhang C, Zhang L, Xiao X, Das A, Zhou Y, Yuan B, Morris M, Zhao B, Chen Y. Transfusion of CXCR4-primed endothelial progenitor cells reduces cerebral ischemic damage and promotes repair in $\mathrm{db} / \mathrm{db}$ diabetic mice. PLoS One. 2012;7(11):e50105.

36. Newcomb JD, Willing AE, Sanberg PR. Umbilical cord blood cells. In Methods in Molecular Biology, Neural Cell Transplantation. New York: Humana Press, 2009: 119-136.

37. Makinen S, Kekarainen T, Nystedt J, Liimatainen, T, Huhtala T, Narvanen A, Laine J, Jolkkonen J. Human umbilical cord blood cells do not improve sensorimotor or cognitive outcome following transient middle cerebral artery occlusion in rats. Brain Res. 2006;1123(1):207-15.

38. Zawadska M, Lukasiuk K, Machaj EK, Pojda Z, Kaminska B. Lack of migration and neurological benefits after infusion of umbilical cord blood cells in ischemic brain injury. Acta Neurobiol Exp (Wars). 2009;69(1):46-51

39. Angels FM, Arboix A, Krupinski J. Angiogenesis, neurogenesis and neuroplasticity in ischaemic stroke. Current Cardiology Reviews. 2010; 6(3): 238-44.

40. Becker S. A computational principle for hippocampal learning and neurogenesis. Hippocampus. 2005;15(6):722-38.

41. Kempermann G, Song H, Gage F.H. Neurogenesis in the Adult Hippocampus. Cold Spring Harb Perspect Biol. 2015 ;7(9):a018812.

42. Namba T, Mochizuki H, Onodera M, Mizuno Y, Namiki H. The Fate of Neural Progenitor Cells Expressing Astrocytic and Radial Glial Markers In The Postnatal Rat Dentate Gyrus. Eur J Neurosci. 2005;22(8):1928-41.

\author{
Abbreviations \\ rt-PA : Recombinant tissue- Plasminogen Activator \\ FDA : Food and Drug Administration \\ cbMNC : Cord Blood Mononuclear Cell \\ MCAO : Middle Cerebral Artery Occlusion \\ IA : Intraarterial \\ IV : Intravenous \\ TUJ1 : Class III Beta Tubulin \\ GFAP : Glial Fibrillary Acidic Protein \\ VEGF : Vascular Endothelial Growth Factor \\ HSC : Hematopoietic Stem Cell \\ MSC : Mesenchymal Stem Cell \\ EPC : Endothelial Progenitor Cell \\ NIHSS : National Institutes of Health Stroke Scale \\ CBF : Cerebral Blood Flow \\ PBS : Phosphate Buffer Saline \\ NIH : National Institutes of Health \\ SGZ : Subgranular Zone \\ BDNF : Brain-Derived Neurotrophic Factor \\ BBB : Blood Brain Barrier \\ HGF : Hepatocyte Growth Factor \\ IGF-1 : Insulin Growth Factor-1 \\ IL-6 : Interleukin-6 \\ IL-10 : Interleukin-6 \\ IL- $\beta \quad$ : Interleukin beta \\ GC-SF : Granulocyte Colony-Stimulating Factor \\ eNOS : Endothelial Nitric Oxide Synthase \\ CXCR4 : Chemokine Receptor Type 4 \\ SDF-1 : Stromal Cell-Derived Factor-1 \\ Ca1 : Cornu Ammonis 1 \\ CA3 : Cornu Ammonis 3 \\ TNF- $\alpha$ : Tumor Necrosis Factor- $\alpha$
}




\section{Potential Conflicts of Interests}

None

\section{Sponsor / Grants}

This work has been funded by a grant from Universitas Indonesia "Hibah Publikasi Internasional Terindeks Untuk Tugas Akhir Mahasiswa UI 2016".

\section{Acknowledgements}

We thank the National Institute of Health Research and Development (litbangkes) Indonesia for providing animals laboratory, Department of Pathology Anatomy, Faculty of Medicine, Universitas Indonesia for assistance in histological analysis and Integrated Care Unit for Stem Cell Therapy, National hospital Ciptomangunkusumo for preparing the cells.

\section{Corresponding Author}

Ahmad Sulaiman Alwahdy, Neurology Department, Medical Faculty University of Indonesia/ Ciptomangunkusumo National Hospital, Muhtar street Bojongsari Sawangan Depok No.7, 16516, Indonesia; Email : ule842002@yahoo.com 